Deliberationes tudományos folyóirat 14. évfolyam 1. szám 2021/1, 120-127. Kézirat beérkezése: 2021.04.28.

Kézirat befogadása: 2021.08.16.

DOI: 10.54230/Delib.2021.1.120
Deliberationes Scientific Journal Vol.14; Ed.No. 1/2021, pages:120-127

Paper submitted: 28th April 2021

Paper accepted: 16th August 2021 DOI: 10.54230/Delib.2021.1.120

\title{
AZ ÁLLAMI ÉS NEM ÁLLAMI ELLÁTÓ SZOCIÁLIS REND- SZEREK SZOLGÁLTATÁSAINAK, SZOLGÁLTATÁSI SZINERGIÁINAK FELTÁRÁSA A HATÉKONYABB MÜKÖDÉS SZEMPONTJÁBÓL
}

Birher Nándor

Gál Ferenc Egyetem, Teológiai Kar

\begin{abstract}
Absztrakt
A munka célja, hogy bemutassa a folyamatszabályozás fontosságát a szociális rendszerek működtetése során is. A PDCA ciklus ill. a kapcsolati hálózatok tudatos alakítása egyaránt fontos az intézmény hatékonyságának növelése során.
\end{abstract}

Kulcsszavak: folyamat, irányítás, szociális terület, minőség, kapcsolatok

\section{EXPLORING THE SERVICES AND SERVICE SYNERGIES OF STATE AND NON-STATE PROVIDER SOCIAL SYSTEMS IN TERMS OF MORE EFFICIENT OPERATION}

\author{
Nándor Birher \\ Faculty of Theology, Gál Ferenc University
}

\begin{abstract}
The aim of the work is to present the importance of process regulation in the operation of social systems as well. Both the PDCA cycle and the conscious building of social networks are important in increasing the efficiency of the institution.
\end{abstract}

Keywords: process, management, social field, quality, relationships 


\section{BEVEZETÉs}

Az EFOP 3. 6. 1. program ${ }^{1}$ céljai között szerepelt, olyan módszerek kidolgozása, a melyek lehetővé teszik az állami és nem állami szociális rendszerek közti hatékonyabb együttmüködést.

Napjainkban azt tapasztalhatjuk, hogy egyre több állami funkció, különösen is az oktatás és a szociális ellátás területéről az egyházi fenntartású intézményekhez kerül. Mindez jellemzően azt jelenti, hogy az egyházi fenntartású intézmények finanszírozásának egy része ill. egyes felügyeleti, ellenőrzési jogkörök maradnak az államnál, a többi feladatot az egyházi intézmények a fenntartójuk által megadott keretek között maguk végzik el.

Az állami feladatok ilyetén kiszervezése azért lehet megalapozott (Birher, 2019) mert az egyházi intézmények oktatási, szociális praxisa évezredekre vezethető viszsza, továbbá vélelmezetten olyan lelki, pasztorális szolgáltatásokat tudnak nyújtani, amelyek az egész társadalom számára értékesek lehetnek (Birher \& Homicskó, 2019).

Az egyházaknak kötelessége az általuk nyújtott értékekre felhívniuk a teljes társadalom figyelmét, különösen is azért, mert a jelentős változásokat (ahogy azt a változásmenedzsment tudományi is megállapítja) jelentős ellenállás is kíséri.

A változást mindig érdemes a „mérnök” és a „pszichológus” szempontjai szerint egyaránt menedzselni, ill. a sikerkritériumokat is így meghatározni. Ahhoz, hogy a változást sikeresnek tekintsük, a mérnök szemszögéből meg kell felelni az elvárt üzleti teljesítménynek, a pénzügyi és statisztikai elvárásoknak. Mindez csak jól szervezett menedzsment rendszer segítségével történhet.

A pszichológus szempontjai a munkával való elégedettség, a szervezettel való azonosulás és a termelékenység növelése. Mindennek az alapja pedig a személyes értéktudat és a folyamatok minőségképességének az egybeesése.

Amikor tehát arról beszélünk, hogy a szolgáltatásokat ill. a szolgáltatási szinergiákat javítani kell, akkor igazából arról van szó, hogy

- $\quad$ ki kell alakítani a megfelelő minőségkultúrát,

- $\quad$ ki kell alakítani az emberre fókuszáló humánerőforrás kezelést és

- harmadikként képessé kell tenni a szervezetet arra, hogy a kapcsolati hálókat alakítson ki, tartson fenn, és tudatosan menedzseljen.

Ugyan szinte végtelen számú a változásmenedzsmentre vonatkozó modellek száma, egyet példaképp kiemelünk közülük, mivel a példában szereplő szempontok jellemzően előkerülnek a többi modellben is. Az ADKAR ${ }^{2}$ modell szerint a változás

1 A tanulmány az EFOP-3.6.1-16-2016-00008 Intelligens élettudományi technológiák, módszertanok, alkalmazások fejlesztése és innovatív folyamatok, szolgáltatások kialakítása a szegedi tudásbázisra építve címü projekt keretében készült.

2 https://www.prosci.com/adkar/adkar-model, letöltve: 2021. 01. 08. 
során az alábbi öt szempontot kell folyamatosan szem előtt tartani. Ezek a szempontok minden, egyházi fenntartásba kerülő intézmény változásmenedzsmentjénél is elő kell, hogy kerüljenek.

1. A (Awareness) az elvárt változás világos megfogalmazása.

2. D (Desire) a változás melletti elköteleződés.

3. K (Knowledge) a változás folyamatának tudatosítása.

4. A (Ability) képesség az újdonság alkalmazására.

5. R (Reinforcement) a megtörtént változás stabilizálása.

Ahogy látjuk, ezen szempontok szerint a fenntartónak, az intézmény vezetőjének, minden munkavállalónak, és a külső érdekelteknek kell együttmüködniük. Napjainkban sajátos szerepet kaphat ebben a folyamatban a korábbi fenntartó, az állam is.

Kifejezetten fontos lehet - figyelemmel a finanszírozás kérdésére is - hogy már az állam is, mint az egyik jelentős finanszírozó határozza meg világosan az elvárásait az új fenntartóval szemben. Kényessé teszi a kérdést, hogy az elvárásokat ugyan világosan kell megfogalmazni, azonban egyúttal úgy is, hogy az ne sértse az egyházak autonómiáját. Ezen a területen jelentős feladatai vannak az Állami Számvevőszéknek is, akinek felügyelnie kell a költségvetési források hatékony felhasználását. Jó gyakorlat az Állami Számvevőszék azon gyakorlata, amely során nem csak egyszerüen ellenőriz, hanem preventív jelleggel szemléletet is formál a források hatékony és megfelelő felhasználásával kapcsolatban.

Összességében elmondható, hogy a világos feladatmeghatározás, és a teljesítmény mérése és a teljesítményhez rendelt forrásbiztosítás lehet az alapja annak, hogy kormányzatoktól függetlenül, hosszú távon, kellő hatékonysággal tudjanak az egyházi intézmények működni.

\section{AZ IRÁNYÍTÁSI RENDSZEREK (KÜLDETÉS, CÉL, VEZETÉS)}

Egészen addig nem beszélhetünk szolgáltatási szinergiákról, amíg a saját folyamatainkkal nem vagyunk tisztában. Éppen ezért az első lépés a saját célok és feladatok definiálása, amelyekből levezethetők lesznek a tényleges folyamatok is.

Az intézmény célját, vízióját a fenntartó adja meg, a finanszírozó objektív követelményeinek is megfelelve. Ezt követően az intézmény vezetöje meghatározza a célokat a stratégiai céloktól az egyes akciótervekig bezárólag, beleértve a minőségcélokat is. Ezen elvárások fényében kerül kialakításra az intézmény szervezeti rendje, amely alkalmas arra, hogy olyan folyamatokat működtessen, amelyek képesek a kívánt célkitűzések elérésére.

Tudjuk, hogy a valóság ennél nagyon gyakran sokkal spontánabb, az egyes célok és víziók nem jelennek meg tudatosított, mérhető formában. Helyette a szokás vagy a privilégium a folyamatszabályozó. Mindez jelentős kockázatokkal járó müködéshez 
vezethet, amelyet egy fenntartónak sem szabadna vállalnia. Még ennél is veszélyesebb, ha csak formális folyamatszabályozók vannak, azaz formálisan létezik a szervezetnél pl. integritás-szabályozás, minőség-irányítás, azonban ezek a szabályozók érdemben nem hatják át a mindennapi müködést. Mindez feleslegesen és megtévesztő módon von el energiákat a szervezetektől.

A mai komplex, hálózatos valóságban a szolgáltatási szektor is csak fokozott tudatosság mellett müködtethető. A tudatosságnak a szervezetek müködtetése esetén jelenleg nincs más ismert formája, mint a folyamatszabályozás. Éppen ezért az egyházi fenntartású intézmények számára is alapvető követelmény a szabályozottság és önértékelés kultúrájának a megvalósítása.

Ezen túlmenően az egyházi intézményeknek van egy további felelőssége is. Számukra a hatékonyság nem lehet az egyetlen és kizárólagos szempont. Folyamatosan figyelemmel kell lenniük a társadalmi szolgálat és a munkavállalók szolgálatának a szempontjaira is. Ráadásul mindezt a vallási elvárásokkal összhangban kell tenniük. Mindez azonban csak akkor valósítható meg, ha ezeket a szempontokat is kellöen egzakt módon tudják meghatározni.

\section{FOLYAMATSZEMLÉLET BEVEZETÉSE}

Több hazai gyakorlat alapján láthattuk, hogy az állami, önkormányzati szektorban a klasszikus vállalatirányítási ill. minőségirányítási rendszerek legfeljebb csak formálisan képesek müködni (Veress 2014). Ennek tanulságos példája lehet a felnőttképzéshez kapcsolódó minőségirányítási rendszerek kudarca. Ezzel együtt azonban nem megengedhetö, hogy a rossz példáktól elbátortalanodva ne vegyük észre a folyamatszabályozás fontosságát az intézménymüködtetés minden területén. A probléma forrása jellemzően abban áll, hogy a vezetés nem rendelkezik kellő ismeretekkel a folyamatszabályozással kapcsolatosan, és ezért nem képes a szervezetéhez valóban illeszkedő szabályozók ténylegesen müködő kialakítására.

Az első lépés tehát nem lehet más, mint a folyamatszabályozás lényegének megismertetése a vezetőkkel, ezt következően pedig a szükséges erőforrások biztosítása következik azzal az elvárással párhuzamosan, hogy a folyamtok müködtetése nem kerülhet többe, mint amennyi hasznot termelnek. Azaz a vállalatirányításnak és minőségbiztosításnak bizonyítható módon kell növelnie a termelési, szolgáltatási folyamatok hatékonyságát.

A következőkben nagyvonalakban bemutatjuk, hogy mik lehetnek a folyamatszabályozás alapjai ${ }^{3}$.

1, „Bármely tevékenység, amely erőfor rásokat használ, és amelyet úgy irányítanak, hogy bemeneteket kimenetekké alakítson át, folyamatnak tekinthető. Az egyik folyamat kimenete gyakran egyben a következő folyamat közvetlen bemenetét is jelenti.” Elsődleges feladat tehát az erőforrásokat használó szervezeteknél a folyamatok

3 A folyamatszabályozás bemutatása során az ISO 9001 szabványt vesszük alapul. 
minél pontosabb leírása. Világos választ kell adni a kérdésre: „mit csinál a szervezet?”. Tiszában kell lenni az elvárásokkal, a hozzáadott értékkel, a jobbíthatóság területeivel, az objektív mérőszámokkal egyaránt.

2, Meg kell érteni, és alkalmazni kell a "Plan-Do-Check-Act" (PDCA), vagy Deming-ciklus néven ismert módszert.

- Plan: (tervezés): azoknak a céloknak és folyamatoknak a megállapítása, amelyek a vevői követelményeknek és a szervezet politikájának megfelelő eredmények eléréséhez szükségesek, azaz meg kell határozni, hogy mit és hogyan akarunk elérni. Ezt követően a meghatározott célok szerint kell eljárni.

- Do: (végrehajtás): a folyamatok bevezetése; azonban mérhető módon meg kell vizsgálni, hogy a folyamatok eredménye az lesz-e, ami az elvárás volt.

- Check: (ellenőrzés): a folyamatok és a termékek figyelemmel kísérése, mérése és összehasonlítása a célokkal és elvárásokkal, valamint az eredmények bemutatása.

- Act: (intézkedés): intézkedések megtétele a folyamat müködésének folyamatos fejlesztésére.

Miután láthatóvá válik, hogy az elvárásoknak megfelelően működik a folyamat, lehetőség van a „sztenderdizációra”, azaz valamilyen szabályleírásban való rögzítésre (pl. SZMSZ vagy egyéb szabályzat).

3, Világossá kell tenni, hogy a teljes folyamatszabályozásért az első számú vezető a felelős. Egyszerü példával: a folyamatosan rosszul teljesítő munkavállaló eredménytelenségét nem lehet egyszerủen csak a rosszul teljesítő számlájára írni. Lehet, hogy a munkakörülményekkel, a munkafeltételekkel, a képzéssel, a hr osztállyal van a probléma, ami máris közvetlen vezetői felelősség lehet. Sosem egyszeri problémát, hanem folyamatszabályozást kell szem előtt tartani.

Ezen túlmenően a vezetők felelőssége, hogy a szervezetnek egyértelmű, világos, mérhető (és folyamatosan mért), mindenkiben tudatosított, erőforrásokkal biztosított minőségpolitikája és minőségcéljai legyenek.

4, Tisztában kell lenni a szervezet külső és belső kommunikációjával, továbbá meg kell lennie azoknak az ellenőrzési módoknak is, amelyek a folyamatszabályozás müködését vizsgálják. A vezetőségi átvizsgálás során meg kell győződni arról, hogy a vezető által elvárt folyamatok valóban az elvárás szerint müködnek-e? Ez a vezetőtől magától is folyamatos önreflexiót és önkritikát követel meg, elfogadva azt, hogy az intézménye „mindig lehet jobb”.

5, Nagyon nagy jelentősége van a „fogyasztóval” való kapcsolattartásnak, ill. annak a ténynek, hogy a szervezet azonosítsa, ki is az ő termékének a felhasználója. Ennek a szempontnak mind a mikrominőségügy (közvetlen felhasználó, pl. kliens), mind a makrominőségügy (közvetett felhasználó, pl. egyház, állam) elvárásait figyelemmel 
kell követnie. A vevők, fogyasztók elégedettségét folyamatosan mérni kell, ill. a kapott eredmények alapján intézkedéseket kell hozni.

6, Részben a makrominőségügy társadalmi szintű elvárásai, részben az egyéb érdekeltek elvárásai miatt fontos lehet a szervezet társadalmi beágyazottságának a vizsgálata és folyamatszabályozása, elsősorban a kapcsolati rendszerek menedzselésén keresztül, amelyet a következő pontban mutatunk be.

\section{A KAPCSOLATI RENDSZEREK TUDATOS MENEDZSELÉSE}

Az intézmények önazonosságának meghatározását követően képessé válik arra, hogy megfelelően menedzselje a kapcsolatait is. A kapcsolatok alapvető distinkciója a presztizs ill. a befolyás szerinti megkülönböztetetés. Ha egy szervezetnek sok a lehetősége arra, hogy más szervezeteket megszólítson, magas befolyású szervezetről beszélünk. Ha egy szervezetet sokan keresnek meg, akkor magas presztizsű szervezetről van szó. A szervezet elhelyezése a kapcsolatok rendszerében ezzel a két mérőszámmal már jól jellemezhető lehet. Minden szervezetnek alapvető fontosságú tudatosítania, hogy hogyan használja a befolyás- és presztízs képességeit. Ezektől a szempontoktól indul ugyanis a sikeres működés.

Ezen túlmenően három alapvető kapcsolat típust határoz meg a szakirodalom, jellemzően egyének vonatkozásában, azonban analóg módon értelmezhetők ezek csoportokra is. A társadalmi kapcsolatok alaptípusai a gyenge és az erős kapcsolatok (Granovetter, 1973). Ezt a megközelítést pontosítja néhány olyan kutatás, amelyik külön vizsgálja az álla mpolgár, vagy a szervezetek és az állami, önkormányzati intézményrendszer (hivatalok) viszonyát, így három kapcsolati formát különböztetve meg: a bonding, bridging, linking típusú kapcsolatokat.

Itt a bonding típusú kapcsolat leginkább az erős, másokat kizáró kapcsolatokra vonatkozik, ilyen zárt társadalmi egységek például a családok, vagy a szoros barátságok, intézmények esetén az egy fenntartó alatt közvetlen kapcsolatban működő szervezetek.

A bridging kapcsolat a gyenge kapcsolatnak feleltethető meg. Ide tartoznak azok az intézmények, amelyek valamilyen közös érdek mentén, jellemzően eseti jelleggel müködnek együtt. Ezek a kapcsolatok lehetnek azok, amelyek számosságának növelése erősítheti az egyházi intézményrendszert is. Jellemzően ilyen kapcsolatok lehetnek az azonos területen müködő egyházi és nem egyházi intézmények kapcsolatai. Ezek a kapcsolatok adják az intézményrendszer ellenállóképességét, a kitettségének a csökkentését, így ezek menedzselése különösen is fontos lehet.

Számunkra jelen esetben az az új kategória az érdekes, amelyik valamilyen módon ötvözi az előző kettő sajátosságait, egy speciális célra szerveződött erős és gyenge kapcsolati komplexitásként. A linking típusú (Putnam, 1993) kapcsolatokat a következők szerint jellemezhetjük:

„A «linking», vagyis összekapcsoló társadalmi tőke összeköti a különböző társa- 
dalmi csoportokat, a civil társadalom és a kormányzat, illetve más hierarchikusan elkülönülő társadalmi egységek összekapcsolását szolgálja. Mint ilyen egyaránt lehet a civil társadalom és a kormányzat közötti jobb együttműködést elősegítő «áttétel», de lehet korrupciós kapcsolatrendszer is. (Benák, Bonding)" Jellemzően itt szervezetek kapcsoltságáról van szó, azonban a kijelentések érvényesek az egyes személyek és a hierarchikusan elkülönülő más intézmények kapcsolatára is. Ezt erősíti meg egy másik tanulmány: „az átívelő kötések az egyén és az intézmények és egyéb rendszerszerü képződmények között átjárást és az ebből adódó előnyöket táplálják.(Messing, 2006)" Esetünkben a linking típusú kapcsolat jellemző példája lehet az egyházi intézmények és az állam, vagy az önkormányzat kapcsolata.

Az egyházi intézményeknek fel kell mérniük a meglévő kapcsolati rendszerüket, meg kell vizsgálniuk a kapcsolataik típusát, irányát, erősségét, ill. a kapcsolat formalizálásának a módjait (szerződés, szóbeli megállapodás, szokás, etc.), ezeknek a kapcsolatoknak a kezelését pedig bele kell illeszteniük az intézményi stratégiába. A kérdéskörben, egy speciális területen, a kórházi lelkigondozásban már rámutattak arra, hogy mennyire fontos a szakemberek együttműködése, lényegében felekezetektől függetlenül (Tésenyi, 2017).

\section{ÖsSZEGzÉS}

Megállapíthatjuk, hogy az egyházi fenntartású intézményeknél - figyelemmel a küldetésükre - kiemelten fontos a szervezeti menedzsment, a belső identitás megerösítése, ezzel párhuzamosan pedig a kapcsolati rendszerek tudatos kialakítása és felügyelete. Csak ezen a módon válik lehetségessé, hogy az egyházi intézményrendszer a lehető legfüggetlenebb módon legyen képes a feladatát ellátni.

Kapcsolattartó szerző:

Birher Nándor

Gál Ferenc Egyetem,

Teológiai Kar

6720 Szeged

Dóm tér 6.

birhernandor@gmail.com
Corresponding author:

Nándor Birher

Faculty of Theology

Gál Ferenc University

Dóm square 6.

6720 Szeged, Hungary

birhernandor@gmail.com

\section{IRODALOMJEGYZÉK}

Birher, N. (2019). A közigazgatás társadalmi megítélésének változása a közigazgatási birói gyakorlat fényében. Nemzeti Közszolgálati Egyetem Közigazgatási Továbbképzési Intézet. https://nkerepo.uni-nke.hu/xmlui/bitstream/ handle/123456789/16051/A\%20kozigazgatas\%20tarsadalmi\%20megitelesenek\%20 valtozasa.pdf;jsessionid=A1BC675EDA26593C26E459503CF96240? sequence $=1$, letöltve: 2021. 01. 08. 
Birher, N., \& Homicskó, Á. (eds.) (2019). Az egyházi intézmények müködtetésének etikai alapjai. Károli Gáspár Református Egyetem Állam- és Jogtudományi Kar. https:// ajk.kre.hu/images/doc5/dokumentumok/honlapra_Az_egyhazi_intezmenyek_ mukodtetesenek.pdf. letöltve: 2021. 01. 08.

Benák M. (2007). Bonding, bridging, linking. A mikrotársadalmi szolidaritás szintjén lévő kapcsolatok István-aknán. Acta-Sociologia Pécsi Szociológiai Szemle, 2(1), 5761. https://doi.org/10.15170/AS.2007.2.1.4

Messing V. (2006). Lyukakból szőtt háló: háztartások közötti támogató kapcsolatok roma és nem roma szegények körében. Szociológiai Szemle, 16(2), 37-54. https:// szociologia.hu/dynamic/0602messing.pdf

Putnam, R. D. (1993). Making Democracy Work: Civic Tradition in Modern Italy. Princeton University Press. https://doi.org/10.2307/j.ctt7s8r7

Tésenyi T., Lukács, Á., Járay, M. \& Lukács, G. (2017). Kapcsolathálózati kutatás magyarországi lelkigondozók körében, Embertárs, 15(1) 5-22. https://jezsuitakiado. hu/wp-content/uploads/2020/03/01_tesenyi_lukacs_embertars_2017_01.pdf

Veress, G., Birher, N. \& Nyilas, M. (2014). A minőségbiztositás filozófiája. Jel Kiadó. 